\title{
DERADICALIZATION BASED ON SPIRITUAL NEUROSCIENCE THROUGH
}

\section{ISLAMIC EDUCATION}

\section{Heni Listiana}

Pendidikan Guru Madrasah Ibtidaiyah, Institut Agama Islam Negeri Madura, Pamekasan, Indonesia

\section{email: henilistianabisa@gmail.com}

\section{ABSTRACT}

The development of Islamic Education course materials and deradicalization in learning is one of the efforts to prevent radicalism. Spiritual neuroscience can be used as a tool to study Islamic educational materials and deradicalization. Learning requires neuroscience to know the framework of student's brain. This article discusses three things: (a) course material related to Islamic education and deradicalization; (b) the abstracted materials from a spiritual neuroscience perspective, and (c) models of Islamic educational material development and deradicalization in spiritual neuroscience. This article shows there are four materials related to Islamic education and deradicalization, they are: the reorientation of the meaning of jihâd, Islâm rahmah li al'âlamîn, multicultural values, and the strengthening of the material on love of the mother land. After being analyzed using neurospiritual operators, all such material closely relates to the meaning of life and positive emotions. Thus, Islamic education learning and deradicalization should be able to foster the formation of life meaning and positive emotions in students.

\section{ABSTRAK}

Pengembangan materi Pendidikan Agama Islam (PAI) dan deradikalasi dalam pembelajaran merupakan salah satu upaya tindakan pencegahan tindakan radikalisme. Neurosains spiritual dapat dijadikan sebagai alat untuk menelaah materi-materi Pendidikan Agama Islam (PAI) dan deradikalisasi. Pembelajaran membutuhkan neurosains untuk mengetahui kerangkan kerja otak siswa. Artikel ini membahas tiga hal: (a) materi yang berkaitan dengan Pendidikan Agama Islam (PAI) dan deradikalisasi; (b) materi-materi yang tersarikan akan dikaji dalam perspektif neurosains spiritual; dan (c) model pengembangan materi Pendidikan Agama Islam (PAI) dan deradikalisasi dalam neurosains spiritual. Artikel ini menunjukkan ada empat materi yang berkaitan dengan Pendidikan Agama Islam (PAI) dan deradikalisasi yaitu reorientasi makna jihad, Islâm rahmah li al'âlamîn, nilai-nilai multikultural, dan penguatan materi cinta tanah air. Setelah dianalisis dengan menggunakan operator neurospiritual semua materi tersebut berkaitan erat dengan makna hidup dan emosi positif. Dengan demikian pembelajaran Pendidikan Agama Islam (PAI) dan deradikalisasi harus mampu menumbuhkan terbentuknya makna hidup dan emosi positif pada diri siswa.
ARTICLE HISTORY

Received 27 April 2021

Accepted 27 June 2021

\section{KEYWORDS}

Islam Nusantara; Nahdlatul Ulama; local wisdom; 'urf; islamization; concervatism 


\section{Introduction}

Radicalism threatens the unity of a nation. Therefore, to maintain the integrity of the country, there must be efforts to prevent the emergence of various actions that lead to radicalism. Today, the prevention of radicalism has entered a new chapter. A strategic step has been taken by the government to tackle the problem of radicalism. The President of the Republic of Indonesia has issued presidential regulation (Peraturan Presiden) 7/2021 on the National Action Plan for the Prevention and Countering Violent Extremism Leading to Terrorism in 2020-2021. All levels of education must add material on the prevention of violent extremism and acts of terrorism to their students. Additional materials must be given at all levels of education, namely primary, secondary and high. The trick is that the materials are included in the curriculum of public education and religion.

A study of anti-radicalism educational material has been conducted and formulated into three main concepts. First, the concept of jihâd in the modern era. Second, the multicultural concept, and the third is the concept of learning about compassion. ${ }^{1}$ These three concepts contain rejecting values against all acts of radicalism. The material of rejection of radicalism is derived from the Quran and hadith. All of that material contains values that oppose radicalism. All such materials can be integrated into Islamic religious education materials. ${ }^{2}$

The values derived from the Quran and hadith have manifestly supported the antiradicalism movement. These values are identified as follows: the prohibition of killing, the prohibition of destructiveness, and the command to spread compassion to all mankind. ${ }^{3}$ Meanwhile, according to the explanation of the book of Syifấ' al-Ummah, anti-radicalism values are reflected in the teachings: Islam as religion of peace, prohibition of terror, reorientation of the meaning of jihâd, changes in the behavior of evil in stages, and the concept of government in Islam. ${ }^{4}$

\footnotetext{
${ }^{1}$ Khoiriyah, "Pendidikan Anti-Radikalisme dan Strategi Menghadapinya: Ikhtiar Menyusutkan Gerakan Radikalisme di Indonesia," Tarbiyatuna: Jurnal Kajian Pendidikan Islam, vol. 3, no. 2 (September, 2019): 131-33, https://doi.org/10.29062/tarbiyatuna.v3i2.263.

2 Alhairi, "Pendidikan Anti Radikalisme: Ikhtiar Memangkas Gerakan Radikal," Tarbawi: Jurnal Pendidikan Islam, vol. 14, no. 2 (2017): 109, https://doi.org/10.34001/tarbawi.v14i2.617.

${ }^{3}$ Feri Ferdian and Bustomi Mustofa, "Strategi Pondok Pesantren Al Ma'ruf Kediri dalam Mencegah Paham Radikalisme Agama," Tribakti: Jurnal Pemikiran Islam, vol. 30, no. 2 (2019): 362, https://doi.org/10.33367/tribakti.v30i2.829..

${ }^{4}$ Fathur Rohman, "Pendidikan Islam Anti Radikalisme Melalui Nadham: Telaah Kitab Shifa' Al-Ummah Karya KH. Taufiqul Hakim Bangsri Jepara," Tadris: Jurnal Pendidikan Islam, vol. 13, no. 1 (2018): 78, https://doi.org/10.19105/tjpi.v13i1.1757.
}

23 Deradicalization Based on Spiritual Neuroscience | Heni Listiana 
Among pesantren itself, strengthening anti-radicalism education is sublimated in the thought and action of Ahl al-Sunnah wa al-Jamâ'ah teachings. They range from moderate values (tawassuth), balance (tawâzun), tolerance (tasâmuh $)$, justice (ta'âdul), ${ }^{5}$ sincere values to ideals to improve ukhuwwah islâmîyah (brotherhood of fellow Muslims) ukhuwwah wathanîyah (brotherhood of fellow nations), and ukhuwwah insânîyah (brotherhood of fellow human beings). ${ }^{6}$

Pesantren (Islamic Boarding School) has participated in building a democratic society, promoting gender equality awareness, improving the quality of public services, and encouraging paradigm change in pesantren itself. ${ }^{7}$ Pesantren and madrasa continue to build harmony between human beings, transmit egalitarian, democratic, humanist, inclusive, and civilized characters. ${ }^{8}$ Other views described that the value of this education includes citizenship, compassion, courtesy, fairness, moderation respect for other, respect for the creator, self-control, and tolerance. ${ }^{9}$

Efforts to include anti-radicalism material in Islamic religious education materials are not new. In the literature search, there are several offers of ideas for the integration of antiradicalism education in the curriculum, including strategies to change the philosophy of the curriculum, strengthen the content of the curriculum, make the learning methods flexible and the evaluation appropriate, ${ }^{10}$ as well as integrate moderate insight and compassion into the design of the curriculum of Islamic education. ${ }^{11}$

In addition, efforts were also found to internalize the values of anti-radicalism in education by changing the way of thinking and the formation of Muslim personalities. The purpose of the effort is to emphasize the values of balance (tawâzun), moderate, and promote universal

\footnotetext{
${ }^{5}$ Ach Rofiq, "Living Aswaja sebagai Model Penguatan Anti Radikalisme di Pesantren," Tarbawi Jurnal Pendidikan Islam, vol. 16, no. 1 (2019): 1, https://doi.org/10.34001/tarbawi.v16i1.997.

${ }^{6}$ Saifuddin Chalim, "Pengaruh Misi, Kurikulum, dan Kepemimpinan di Perguruan Tinggi terhadap Perilaku Anti-Radikalisme Mahasiswa," Jurnal Pendidikan dan Kebudayaan, vol. 3, no. 1 (2018): 42, https://doi.org/10.24832/jpnk.v3i1.728 .

${ }^{7}$ Syamsul Ma'arif, "Education as a Foundation of Humanity: Learning from the Pedagogy of Pesantren in Indonesia," JSSER: Journal of Social Studies Education Research, vol. 9, no. 2 (2018): 104, https://doi.org/10.17499/jsser.58854.

${ }^{8}$ Syamsul Ma'arif, Leonard C. Sebastian, and Sholihan Sholihan, "A Soft Approach to Counter Radicalism: The Role of Traditional Islamic Education," Walisongo: Jurnal Penelitian Sosial Keagamaan, vol. 28, no.1 (2020): 1, https://doi.org/10.21580/ws.28.1.6294.

${ }^{9}$ Muh Sya'roni, "Strategi Integrasi Pendidikan Anti Radikalisme dalam Kurikulum SMA/MA," Karangan: Jurnal Kependidikan, Pembelajaran, dan Pengembangan, vol. 1, no. 1 (February, 2019): 37.

${ }^{10}$ Ibid.

11 Jakaria Umro, "Upaya Guru Pendidikan Agama Islam dalam Mencegah Radikalisme Agama di Sekolah," JIE: Journal of Islamic Education, vol. 2, no. 1 (May, 2017): 102.
} 
truth. ${ }^{12}$ Another way that can be taken to develop anti-radicalism educational materials is through character education included in the formal curriculum as well as a hidden curriculum. An example of character education is the building of religious values that can be done to familiarize students to start learning activities with prayer. ${ }^{13}$

Although efforts to address radicalism through Islamic religious education have been widely carried out, the act of radicalism remains in Indonesia. Therefore, this study seeks to respond to the presidential regulation (Perpres) 7/2021, especially concerning the addition of Islamic religious education materials to prevent the occurrence of extremism in Indonesia by using a spiritual neuroscience approach. Neuroscience studies learn about the relationship between the nervous system and human spirituality.

This study is based on three main foundations: first, learning must include the brain in all its activities because the brain performs its function as a controlling source of all human activities. Second, Islamic education is related to the study of the relationship between man and God, as well as human relationships with others. This refers to the use of Islam as a religion of peace. The violence of any kind is contrary to the purpose of Islam. Third, the approach of spiritual neuroscience offers the concept of the meaning of life and positive emotions that can be used as a reinforcement on deradicalization material in Islamic education.

The focus of this study includes three things: first, this study will reveal the development of Islamic education material integration and deradicalization. Second, the abstracted materials will be examined from a spiritual neuroscience perspective. Third, it will portray the model of Islamic education material development and deradicalization in spiritual neuroscience.

This literature research uses a content analysis base. The data source was obtained through the analysis of several literature sources, especially in the field of Islamic education and spiritual neuroscience, including Taufiq Fredrik Pasiak's dissertation with the title Model Penjelasan Spiritualitas dalam Konteks Neurosains, ${ }^{14}$ article of Imroatum Muhimmah and Suyadi with the

\footnotetext{
${ }^{12}$ Muhammad Saekan Muchith, "Radikalisme dalam Dunia Pendidikan," Addin: Media Dialektika Ilmu Islam, vol. 10, no. 1 (2016): 178-79, http://dx.doi.org/10.21043/addin.v10i1.1133.

${ }^{13}$ Saihu and Marsiti, "Pendidikan Karakter dalam Upaya Menangkal Radikalisme di SMA Negeri 3 Kota Depok, Jawa Barat," Andragogi: Jurnal Pendidikan Islam dan Manajemen Pendidikan Islam, vol. 1, no. 1 (2019): 23 , https://doi.org/10.36671/andragogi.v1i1.47.

${ }^{14}$ Taufiq Fredrik Pasiak, Model Penjelasan Spiritualitas dalam Konteks Neurosains (Dissertation, UIN Sunan Kalijaga, Yogyakarta, 2009)
} 
title Neurosains dan Spiritualitas dalam Pendidikan Islam, ${ }^{15}$ article of Fitria Anggraini Dalili, et. al. with the title Hubungan Kinerja Otak dengan Spiritualitas Manusia Diukur dengan Menggunakan Indonesia Spiritual Health Assessment pada Dosen STAIN Manado, ${ }^{16}$ and Imam Hanafi's article with the title Neurosains-Spiritualitas dan Pengembangan Potensi Kreatif. ${ }^{17}$

Data are collected using the search techniques of digital reference sources closely related to the theme. After all, the data collected are then presented, then the exposure of the data is reduced, and the data are built to become a new concept. The use of content analysis or content can help achieve results that prioritize intertextuality and meaning creativity.

In the early stages, researchers identified Islamic educational materials related to radicalism at various reference sources. Then the researchers added one material that is strengthening the material of love of the motherland. This material is considered important because it is closely related to maintaining the unity of the nation to create a harmonious and peaceful life.

In the second phase, researchers analyzed Islamic educational materials related to radicalism with neurospiritual operators. The trick is to convey the concepts presented to all materials and explore the values taught. After that, the abstracted values are associated with neurospiritual operators and dimensions that include them. In the third phase, a model of Islamic education material development and deradicalization was developed.

\section{Development of Islamic Education and Deradicalization Materials}

The material of Islamic education and deradicalization is developed based on existing materials. These include reorientation of the meaning of jihâd, Islâm rahmah li al-âlamîn, and multicultural values. This study adds one material that is considered important for the prevention of radicalism, namely the strengthening on the material of love of the motherland. As for the explanation of the materials can be described as follow:

\footnotetext{
15 Imroatum Muhimmah and Suyadi, "Neurosains dan Spiritualitas dalam Pendidikan Islam," Tadris: Jurnal Pendidikan Islam, vol. 15, no. 1 (2020), https://doi.org/10.19105/tjpi.v15i1.2880.

${ }^{16}$ Fitria Angraini Dalili, Taufiq F. Pasiak, and Sunny Wangko, "Hubungan Kinerja Otak dengan Spiritualitas Manusia Diukur dengan Menggunakan Indonesia Spiritual Health Assessment pada Dosen STAIN

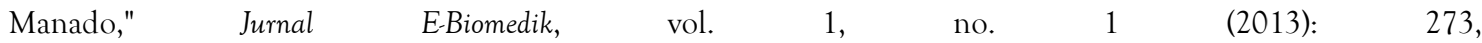
https://doi.org/10.35790/ebm.v1i1.4358.

${ }^{17}$ Imam Hanafi, "Neurosains-Spiritualitas dan Pengembangan Potensi Kreatif," An-Nuha: Jurnal Kajian Islam, Pendidikan, Budaya dan Sosial, vol. 3, no. 1 (July, 2016): 28. 
a. Reorientation of the meaning of jihâd

The meaning of jihâd is far from all activities that contain elements of violence, bring harm to others, and cause difficulties for other human beings. The nature of jihâd will lead to the creation of peace, happiness, and the sustainability of human rights. ${ }^{18}$ Thus, jihâd should be understood as ishlâh (attempt at repair) not ifsâd (the act of destruction) or qitâl (attempt to kill). ${ }^{19}$ The misconception of the meaning of jihâd can cause a variety of problems, one of which is to tear down the unity of the nation. Therefore, every Muslim who is a citizen of Indonesia is expected to participate in disseminating Islamic doctrine as a religion of peace and tolerance.

Imam Samudra, one of the perpetrators of the Bali bombings, explained that the actions that had been carried out together with his friends were driven by the spirit of jihâd. In short, they carried out the bombing because of the call of jihâd. Based on this, it is clear that the difference in understanding jihâd between the bombers and the Indonesian Ulama Council (MUI). For MUI, their actions are already in the category of terrorism. To distinguish the actions of jihâd and terrorism, MUI makes a very clear boundary.

According to MUI, there are three differences between jihâd and terrorism both from nature, purpose, and action. First, the nature of terrorism can bring damage (ifsâd), while jihâd has a nature of improvement (ishlâh). Second, the purpose of acts of terrorism is to create panic in society and government, while jihâd aims to strengthen the religion of Islam and protect people who want to damage it. Third, terrorism activities have no consideration of rules and values and neither does a clear target. While jihâd must adhere to some rules and principles of warfare with the regulation on specific targets for attacks. ${ }^{20}$

The verses of the Quran relating to jihâd or qitâl are summarized in al-Mâ'idah (5): $32,{ }^{21}$ al'Ankabût (29): 69, ${ }^{22}$ and al- $\underline{\text { Hajj }}$ (22): 30-40.23 Misinterpretation occurs in understanding the meaning of jihâd in the verses above. This inaccurate use was used as a means of justification

\footnotetext{
${ }^{18}$ Muzamil, "Mewujudkan Pendidikan Jihad untuk Melawan Teroris," Turatsuna: Jurnal Keislaman dan Pendidikan, vol. 1, no. 1 (2019): 86.

${ }^{19}$ Alhairi, "Pendidikan Anti Radikalisme," 117.

${ }^{20}$ Novan Ardy Wiyani, "Pendidikan Agama Islam Berbasis Anti Terorisme di SMA," Jurnal Pendidikan Islam, vol. 2, no. 1 (2013): 68, https://doi.org/10.14421/jpi.2013.21.65-83.

${ }^{21}$ Alhairi, "Pendidikan Anti Radikalisme," 116.

22 Abdullah Botma, "Deradikalisasi Paham Keagamaan Melalui Pendekatan Pendidikan Agama Islam dalam Keluarga," Jurnal Ilmiah Iqra', vol. 14, no. 2 (2020): 182, http://dx.doi.org/10.30984/jii.v14i2.1212.

${ }^{23}$ Ibid.

27 Deradicalization Based on Spiritual Neuroscience | Heni Listiana
} 
by followers of radicalism and fundamentalism. Followers of both traditions have often deflected the meaning of jihâd to legitimize their acts of terror around the world, including Indonesia. Indeed, physical jihâd is a part of the meaning of jihâd, but there must be clear rules. However, all acts on behalf of jihâd committed by followers of radicalism, fundamentalism, and terrorism are not among those taught by Islam. And it turns out they have misunderstood the meaning of jihâd. ${ }^{24}$

Based on the suffering of the wrong jihâd action, the meaning of jihâd today is more directed at jihâd against radicalism. The effort that can be made is to show the beauty of the social environment. All elements of society are moving against radicalism under the command of state forces. ${ }^{25}$ The country is a major force against terrorism because the government can take swift and decisive action against the growth dynamics of various forms of flow, differences, and types of campaigns of doctrinal coercion. All actions that threaten the harmonization of national and state life must be strictly acted upon. One form of state action is the enactment of presidential regulation (Perpres) 7/2021.

b. Islâm rahmah li al'âalamîn

This material refers to the meaning of Islam as noble teaching delivered by Muhammad PBUH. Hence the ultimate goal of the noble teachings will bring a positive impact, show an inclusive attitude, comprehensive and holistic understanding. Based on that, the ideas are perfect, they contain the sacred and the divine, and are more authentic. ${ }^{26}$ Islam declares itself as a religion of mercy for the universe (rahmah li al'âlamîn). This idea is following al-Anbiyâ' (21): 107 which means "We did not send you (Muhammad) except as a mercy (mercy) for the universe."

Referring to the verse, Islamic teachings mean peace. The purpose of Islam on this earth is to bring peaceful missions. Based on this, the dimension of peace in Islam includes three things. First, the dimension of godliness (tauhîd), namely Allah. God must be placed as an inspiring source of peace for each of his beings. Second, the dimension of humanity (insânîyah). The man was created by God in a holy condition (fithr). Therefore, a man has basic

\footnotetext{
24 Aceng Kosasih, Wawan Hermawan, and Supriyono, "Model Pendidikan Anti Teroris Melalui Internalisasi Nilai Dzikir di Pesantren," Jurnal Pendidikan Ilmu Sosial, vol. 25, no. 1 (2016): 109, https://doi.org/10.17509/jpis.v25i1.3673.

${ }^{25}$ Muzamil, "Mewujudkan Pendidikan Jihad," 85.

${ }^{26}$ Muhammad Makmun Rasyid, "Islam Rahmatan Lil Alamin Perspektif KH. Hasyim Muzadi," Epiteme: Jurnal Pengembangan Ilmu Keislaman, vol. 11, no. 1 (2016): 99, https://doi.org/10.21274/epis.2016.11.1.93-116. 
values for peaceful, calm, harmonious, and tolerant life. Third, the natural dimension (kaunîyah). God created nature for man. Therefore, man is expected to be able to manage it well, so that it can meet his needs. ${ }^{27}$

Islam has a very rich meaning of divine spirituality. The meaning of spirituality is reflected in the life attitude of its followers who are humanist, inclusive, tolerant, and peaceful. This concept is commonly known as the doctrine of habl min al-nâs. ${ }^{28}$ Every Muslim is obliged to preach Islam with hospitality, wisdom, and peace. Thus Islam is easy to be accepted by the public with full awareness and voluntary. ${ }^{29}$

Furthermore, the implementation of the concept of Islâm rahmah li al'âlamîn can be illustrated through many attitudes. For example, every Muslim should be kind to anyone including non-Muslims. Muslims can cooperate with them in the social activities of the society and the field of statehood. Thus there is a prohibition for Muslims to show attitudes and actions that contain elements of hostility and division. Clearly and unequivocally, that cannot be bargained is related to 'aqîdah (belief).

c. Multicultural values

Multiculturalism arises based on the awareness of the importance of recognizing and appreciating cultural diversity. This awareness will have the power to change public policy. Policies relating to the public interest should accommodate diversity. The purpose of multiculturalism is to create a peaceful and just society. ${ }^{30}$ The multicultural values include tolerance, mutual respect, respect for culture and religion, togetherness, unity, cooperation, solidarity values, ${ }^{31}$ democracy, equality, justice, ${ }^{32}$ and mutual understanding of differences. ${ }^{33}$

${ }^{27}$ Muhammad Iqbal and Najmuddin, "Pendidikan Damai dalam Islam," Jurnal Ilmiah Sains, Teknologi, Ekonomi, Sosial dan Budaya, vol. 1, no. 2 (May, 2017): 71.

${ }^{28}$ Abd. Malik Usman, "Islam Rahmah dan Wasathiyah: Paradigma Keberislaman Inklusif, Toleran dan Damai," Humanika: Kajian Ilmiah Mata Kuliah Umum, vol. 15, no. 1 (September, 2015): 3, https://doi.org/10.21831/hum.v15i1.7637.

${ }^{29}$ Rasyid, "Islam Rahmatan Lil Alamin," 98.

30 Wiyanto, "Implementasi Nilai-nilai Multikultural pada Sekolah Multietnik: Studi Interaksi Sosial di SMA Karangturi," Ecodunamika: Jurnal Pendidikan Ekonomi, vol. 1, no. 3 (2018): 1

${ }^{31}$ Ibid.

32 Aristhopan Firdaus, "Aktualisasi Nilai-nilai Multikultural Melalui Penerapan Model Pembelajaran Kooperatif Tipe Jigsaw pada Mata Kuliah Studi Resolusi Konflik dan Pendidikan Multikultural," Jurnal PAI Raden Fatah, vol. 1, no. 2 (2019): 215, https://doi.org/10.19109/pairf.v1i2.3250 .

${ }^{33}$ Fransiska, "Menumbuhkan Nilai-nilai Multikultural di TK Graha Mulia Sintang," Dunia Anak: Jurnal Pendidikan Anak Usia Dini, vol. 1, no. 1 (2018): 10, https://doi.org/10.31932/jpaud.v1i1.281. 
The principles of planting the values of multicultural education are three: openness, tolerance, and unity in diversity. ${ }^{34}$

d. Material of love of the motherland

The main foundation to maintain the integrity of state life is the growth of awareness on the love of the homeland. The strong love for mother earth will be the driving force to deliver the realization of the nation's goals. The goal is the realization of a society that lives fairly and prosperously. The requirement of achieving this goal is that every citizen living on the Indonesian earth must uphold and preserve the independence that has been achieved by the Indonesian nation.

As a part of Indonesia, every citizen needs to express his/her love of mother land. The expression of love can be realized in every individual, namely the sense of pride, belongingness, respect, respect, and loyalty to the country. This attitude can be reflected in the behavior of maintaining, protecting, and defending the homeland, the emergence of a sincere attitude of sacrifice for the sake of the nation and the country, and the growing love for customs and culture that has been inherited by ancestors. ${ }^{35}$ The condition clearly describes the meaning of love of the motherland. That is the emergence of a high love for the place of life of a person from the process of birth, development, and benefit of living in it. So this feeling of love is directed to be a sense of pride and loyalty to his country. ${ }^{36}$

Because of the importance of the concept of loving of the motherland, education needs to develop the concept in learning material. The goal is for students to have the concept of knowledge, thinking, and action that proves a sense of loyalty, care, and respect for language and the environment. ${ }^{37}$ Strengthening the material of love of this country becomes one way to build the soul of every citizen. One of the roles of education is to preserve sustainability of the country and the nation of Indonesia. The way that can be taken is to raise awareness of the pride in students to their homeland. Thus, students can gain knowledge of the love of the

${ }^{34}$ Ihsan Ahmad, "Peran Pendidikan Multikultural di Perguruan Tinggi Islam di Papua: Studi Kasus di STKIP Muhammadiyah Sorong Papua Barat)," Citizenship Jurnal Pancasila dan Kewarganegaraan, vol. 5, no. 1 (2017): 24, http://doi.org/10.25273/citizenship.v5i1.1160.

${ }^{35}$ Dina Anika Marhayani, et. al., "The Socialization of Patriotism Through the Screening of the National Defense Film Against Border Area Communities," International Journal of Public Devotion, vol. 2, no. 2 (2020): 44, http://dx.doi.org/10.26737/ijpd.v2i2.1643.

${ }^{36}$ Desi Ulifah and I Made Suwansa, "Strategi Sekolah dalam Menanamkan Sikap Cinta Tanah Air Pada Peserta Didik di SMPN 1 Tarik Kabupaten Sidoarjo," Kajian Moral dan Kewarganegaraan, vol. 8, no. 3 (2017): 879.

${ }^{37}$ Irzal Anderson and Maria Ulfa, "Penerapan Nilai Cinta Tanah Air pada Pembelajaran Pendidikan Kewarganegaraan di Kelas IV Sekolah Dasar," Jurnal Gentala Pendidikan Dasar, vol. 3, no. 1 (2018): 147, https://doi.org/10.22437/gentala.v3i1.6776.

30 Deradicalization Based on Spiritual Neuroscience | Heni Listiana 
homeland in the form of pride in Indonesia which makes them able to share their culture with others confidently.

\begin{tabular}{|c|c|c|c|}
\hline No. & $\begin{array}{c}\text { Development of } \\
\text { integration of Islamic } \\
\text { education and } \\
\text { deradicalization }\end{array}$ & Concepts raised & Values taught \\
\hline 1 & $\begin{array}{l}\text { Reorientation of the } \\
\text { meaning of jihâd }\end{array}$ & $\begin{array}{l}\text { Jihâd as ishlâh } \\
\text { (improvement) }\end{array}$ & $\begin{array}{l}\text { The creation of peace, } \\
\text { happiness, and sustainability of } \\
\text { human rights }\end{array}$ \\
\hline \multirow[t]{3}{*}{2} & \multirow[t]{3}{*}{$\begin{array}{l}\text { Islâm rahmah li al- } \\
\text { 'âlamîn }\end{array}$} & $\begin{array}{l}\text { a. Dimension of } \\
\text { tauhîld (deity) }\end{array}$ & $\begin{array}{l}\text { Allah is an inspiration and a } \\
\text { source of peace. }\end{array}$ \\
\hline & & $\begin{array}{l}\text { b. Dimension of } \\
\text { insânîyah } \\
\text { (humanity) }\end{array}$ & $\begin{array}{l}\text { Human beings are created holy } \\
\text { and have basic values to live in } \\
\text { peace, calm, harmony, and } \\
\text { tolerance. }\end{array}$ \\
\hline & & $\begin{array}{ll}\text { c. } & \text { Dimension of } \\
& \text { kaunîyah (natural) }\end{array}$ & $\begin{array}{l}\text { Nature is created for man to be } \\
\text { well organized to meet his } \\
\text { needs. }\end{array}$ \\
\hline 3 & Multicultural values & Humanism & $\begin{array}{l}\text { The attitude of tolerance, } \\
\text { respect for culture, respect for } \\
\text { religion, strengthening } \\
\text { togetherness, strengthening } \\
\text { unity, establishing cooperation, } \\
\text { the emergence of values of } \\
\text { solidarity, democracy, equality, } \\
\text { justice, and mutual } \\
\text { understanding of differences. }\end{array}$ \\
\hline 4 & $\begin{array}{l}\text { The strengthening of } \\
\text { the material love of }\end{array}$ & Nationalism & $\begin{array}{l}\text { Defending, protecting the } \\
\text { homeland, sincerely sacrificing }\end{array}$ \\
\hline
\end{tabular}




\begin{tabular}{|l|l|l|}
\hline the motherland & $\begin{array}{l}\text { for the sake of the nation and } \\
\text { the country, and loving the } \\
\text { culture that has been inherited } \\
\text { by the ancestors. }\end{array}$ \\
\hline
\end{tabular}

Table. 1

Development of Islamic religious materials, concepts, and values of education and deradicalization

\section{Islamic Deradicaltzation Educational Materials in Spiritual Neuroscience Perspective}

The four materials that have been developed will be analyzed using a spiritual neuroscience approach, a neuroscience subdiscipline that specifically discusses the study of the human brain and spirituality. ${ }^{38}$ First, the material of radicalism is closely related to one's understanding of the religious way which cannot be separated from God. Spirituality is also related to God. Second, before a person acts radically which leads to acts of violence, there is process of transformation of knowledge, understanding, value, and belief in his brain (transfer of knowledge). This indicates the brain's close involvement in human life activities, including education, radicalization, and deradicalization. Third, spiritual neuroscience is one way to animate religious spirit by instilling the meaning of life, positive emotional attitudes, spiritual experiences, and ritual behaviors in students.

The focus of neuroscience research includes several things: meditation, prayer, forgiveness, hope, rituals, and myths. ${ }^{39}$ In the view of neuroscience, spirituality is managed by the brain. Therefore, any education, including Islamic religious education and deradicalization, should be developed based on the performance of the students' brain. All spiritual actions in the brain are performed by components of the brain and are called Neurospiritual Operators. These operators consist of the prefrontal cortex, the associate area, the limbic system, and the autonomic nervous system. ${ }^{40}$ This operator has dimensions that can support human life,

\footnotetext{
${ }^{38}$ Hasnida, Masyitoh, and Rusmin Tumanggor, "Spiritual Neuroscience Learning at Aisyiyah East of Tebet, South Jakarta," Asian Journal of Contemporary Education, vol. 3, no. 2 (2019): 111, https://doi.org/10.18488/journal.137.2019.32.111.120.

${ }^{39}$ Pasiak, Model Penjelasan Spiritualitas, p. 19.

${ }^{40}$ Ibid., p. 41. 
namely the meaning of life, positive emotions, spiritual experiences, and rituals. ${ }^{41}$ In this study, the dimensions that are considered to have relevance to the development of Islamic education material and deradicalization are the meaning of life and positive emotions.

First, the dimension of life meaning is the embodiment of the deepening of unique intrapersonal meanings. This dimension is seen in social relationships that live, inspire, and exemplify things that are useful for human life. The emergence of this dimension is a result of the perception of individuals who consider themselves meaningful and valuable so that it should not be wasted. Febri explains five situations related to the meaning of life, namely when a person finds himself; faces to face on two or more options; feels special; irreplaceable and unique; successfully performs responsibilities on complicated conditions; and when experiencing a great spiritual experience. ${ }^{42}$

Radicals, such as suicide bombers, are very likely to have no meaning in life. One of the suicidal impulses was because of a lack of understanding of the meaning of life. ${ }^{43}$ The meaning of life is related to the function of the prefrontal cortex. The three main functions of the prefrontal cortex are to plan for the future, make decisions, determine judgments and have values (judgment and values or moral cognition). If the prefrontal cortex works well, it can color the life better. ${ }^{44}$

The four materials that include the reorientation of the meaning of jihâd, Islâm rahmah li al'âlamin, multicultural values, and the strengthening on the love of the motherland have a relationship with the meaning of life. This is based on analysis: (1) The four materials are the understanding of concepts relating to an individual's relationship with God (religious teachings) and human relationships; (2) The four materials relate to value. This is in line with the expected values of material development, concept, and Islamic education values, and deradicalization; and (3) Through Islamic education learning, students are expected to be able to make good decisions by Islamic goals. The meaning of life relates to the area of association. This area is called the cerebellum brain. In the context of spirituality, this area of association

\footnotetext{
${ }^{41}$ Muhimmah and Suyadi, "Neurosains dan Spiritualitas," 69.

${ }^{42}$ Dalili, Pasiak, and Wangko, "Hubungan Kinerja Otak," 273.

${ }^{43}$ Sulastry Pardede, "Penerapan Terapi Suportif dengan Teknik Bimbingan untuk Mengurangi Dorongan Bunuh Diri pada Pasien Skizofrenia," Teraputik Jurnal Bimbingan dan Konseling, vol. 1, no. 1 (2017): 89.

${ }^{44}$ Dalili, Pasiak, and Wangko, "Hubungan Kinerja Otak," 274. 
includes areas of visual association, attention, orientation, and verbal conceptuality. Human consciousness is processed in this area of the association. ${ }^{45}$

Both dimensions are positive emotions. That is the ability of a man to manage himself in responding to environmental conditions. The form of positive emotions is illustrated in selfconscious attitude, respect, self-motivation, social skills, and self-control. ${ }^{46}$ All his emotions are in the limbic system. As social beings, everyday students connect and communicate with others. These interactions require an emotional management system to overcome fear, anger, aggressiveness, and awkwardness. A person who has emotional intelligence is characterized by five things: the appearance of self-drive, the attitude of understanding self-emotions, regulating emotions, building relationships, and knowing the emotions of others. This interaction process involves the emotional centre and the autonomic nervous system. The involvement of these two parts can create a pleasant and exhilarating situation for ritual practitioners. ${ }^{47}$

The explanation of the analysis of Islamic educational material and deradicalization in spiritual neuroscience can be concluded as follows:

\begin{tabular}{|c|c|c|}
\hline Material & $\begin{array}{l}\text { Neurospiritual operators who play } \\
\text { a role in }\end{array}$ & Dimension \\
\hline $\begin{array}{l}\text { Reorientation of the meaning } \\
\text { of jihâd }\end{array}$ & $\begin{array}{l}\text { Prefrontal cortex } \\
\text { The associate area } \\
\text { - The limbic system }\end{array}$ & $\begin{array}{l}\text { Meaning of life } \\
\text { and positive } \\
\text { emotions }\end{array}$ \\
\hline Islâm rahmah li al-âlamîn & $\begin{array}{l}\text { Prefrontal cortex } \\
\text { The associate area } \\
\text { The limbic system } \\
\text { The autonomic nervous } \\
\text { system }\end{array}$ & $\begin{array}{l}\text { Meaning of life } \\
\text { and positive } \\
\text { emotions }\end{array}$ \\
\hline Multicultural values & $\begin{array}{l}\text { Prefrontal cortex } \\
\text { The associate area } \\
\text { - The limbic system } \\
\text { - The autonomic nervous } \\
\text { system }\end{array}$ & $\begin{array}{l}\text { Meaning of life } \\
\text { and positive } \\
\text { emotions }\end{array}$ \\
\hline
\end{tabular}

${ }^{45}$ Hanafi, "Neurosains-Spiritualitas," 28.

${ }^{46}$ Muhimmah and Suyadi, "Neurosains dan Spiritualitas," 73.

${ }^{47}$ Dalili, Pasiak, and Wangko, "Hubungan Kinerja Otak," 383. 


\begin{tabular}{|l|l|l|}
\hline The strengthening of the & $\begin{array}{l}\text { Prefrontal cortex } \\
\text { material love of the motherland }\end{array}$ & $\begin{array}{l}\text { Meaning of life } \\
\text { and positive } \\
\text { The associate area } \\
\text { The limbic system } \\
\text { The autonomic nervous } \\
\text { system }\end{array}$
\end{tabular}

Table 2

Analysis of Islamic educational materials and deradicalization in the perspective of spiritual neuroscience

Based on the table above, it can be concluded: first, all neurospiritual operators are related to all Islamic education materials and deradicalization. It excludes the autonomic nervous system that is not present in the material reorientation of the meaning of jihâd. This is because this material is not associated with creating fun and exhilarating circumstances. Second, of the four spiritual dimensions, only the dimensions of life meaning and positive emotions are related to Islamic education material and deradicalization.

Model of Islamic Educational Material Development and Deradicalization Based on Spiritual Neuroscience

The development of this model places two main areas, namely Islamic education and deradicalization. First, it relates to radicalism affiliated with religion. Islamic education has an important role to provide strengthening of understanding to all Muslim students about the dangers of radicalism with acts of violence that endanger the unity of the Republic of Indonesia. Second, Islamic education teachers can include a curriculum to prevent violent extremism leading to terrorism in their learning. Third, the function of education is to participate in realizing the national goals contained in the national education objectives.

These materials are developed based on existing materials namely reorientation of the meaning of jihâd, Islâm rahmah li al'âlamîn, multicultural values, and added with the strengthening of the material on love of the homeland. This strengthening material is a manifestation of the importance of raising awareness of students as Indonesian citizens. This means that every student must maintain and preserve the independence that has been obtained. This material will evoke the importance of pride in Indonesia's water, a fertile and 
rich country (gemah ripah loh jinawi). A sense of pride, followed by the spirit of belongingness, will then raise the spirit to guard, protect, and fight anyone who wants to damage the Indonesian nation.

Furthermore, this developed material is reviewed from a spiritual neuroscience perspective. This perspective is a tool for reading such materials concerning spiritual neuroscience. It then produces readings of the brain components responsible for spiritual activity (neurospiritual operators). To sharpen the reading, spiritual dimensions are used very closely with Islamic education materials and deradicalization.

Thefigure is about the model of Islamic educational material development and deradicalization based on spiritual neuroscience:

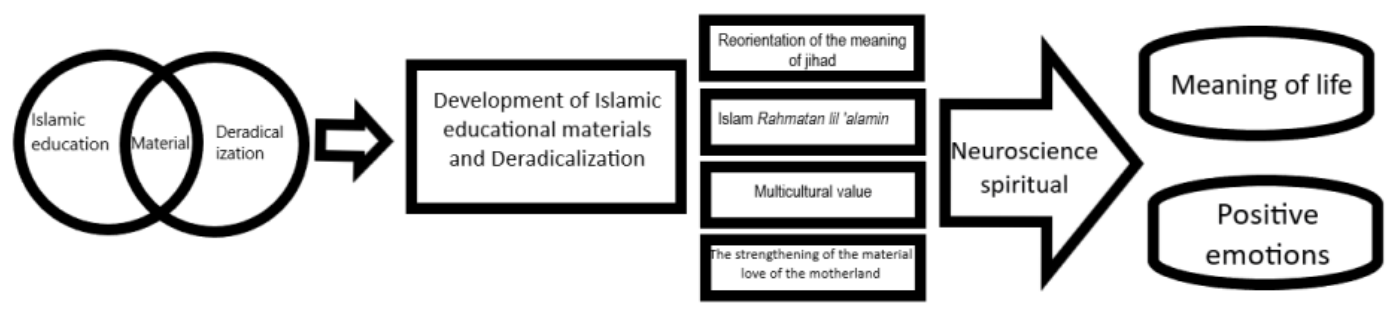

Figure. 1

Model of development of Islamic educational materials and deradicalization based on spiritual neruosains

\section{Conclusion}

Based on the results of the explanation above, it can be concluded: first, the materials related to Islamic education and deradicalization are four: reorientation of the meaning of jihâd, Islâm rahmah li al'âlamîn, multicultural values, and the strengthening of the material on love of the homeland. Second, using spiritual neuroscience as a tool to analyze Islamic educational materials and deradicalization reveal two things: 1) All neurospiritual operators intersect with Islamic educational material and deradicalization; and 2) Spiritual dimensions closely relate to Islamic educational material and deradicalization are meanings of life and positive emotions. Third, the model of Islamic education material development and deradicalization based on spiritual neuroscience that rests on the material reorientation of the meaning of jihad, Islâm rahmah li al'âlamîn, multicultural values, and the strengthening of the material love of the homeland leads to the formation of the meaning of life and positive emotions of students. Further research can be done by compiling Islamic education materials 
and deradicalization from elementary to secondary level so that it can be applied directly in classroom learning.

\section{Reference}

Ahmad, Ihsan "Peran Pendidikan Multikultural di Perguruan Tinggi Islam di Papua: Studi Kasus di STKIP Muhammadiyah Sorong Papua Barat)." Citizenship Jurnal Pancasila dan Kewarganegaraan, 5 (1): 24-31, http://doi.org/10.25273/citizenship.v5i1.1160.

Alhairi. "Pendidikan Anti Radikalisme: Ikhtiar Memangkas Gerakan Radikal." Tarbawi: Jurnal Pendidikan Islam, 14 (2): 109, https://doi.org/10.34001/tarbawi.v14i2.617.

Anderson, Irzal and Maria Ulfa. "Penerapan Nilai Cinta Tanah Air pada Pembelajaran Pendidikan Kewarganegaraan di Kelas IV Sekolah Dasar." Jurnal Gentala Pendidikan Dasar, 3 (1): 145-162, https://doi.org/10.22437/gentala.v3i1.6776.

Botma, Abdullah. "Deradikalisasi Paham Keagamaan Melalui Pendekatan Pendidikan Agama Islam dalam Keluarga." Jurnal Ilmiah Iqra', 14 (2): 171-185, http://dx.doi.org/10.30984/jii.v14i2.1212.

Chalim, Saifuddin. "Pengaruh Misi, Kurikulum, dan Kepemimpinan di Perguruan Tinggi terhadap Perilaku Anti-Radikalisme Mahasiswa." Jurnal Pendidikan dan Kebudayaan, 3 (1): 33 43, https://doi.org/10.24832/jpnk.v3i1.728 .

Dalili, Fitria Angraini Taufiq F. Pasiak, and Sunny Wangko. "Hubungan Kinerja Otak dengan Spiritualitas Manusia Diukur dengan Menggunakan Indonesia Spiritual Health Assessment pada Dosen STAIN Manado." Jurnal E-Biomedik, 1 (1): 270-275, https://doi.org/10.35790/ebm.v1i1.4358.

Ferdian, Feri and Bustomi Mustofa. "Strategi Pondok Pesantren Al Ma'ruf Kediri dalam Mencegah Paham Radikalisme Agama." Tribakti: Jurnal Pemikiran Islam, 30 (2): 362-371, https://doi.org/10.33367/tribakti.v30i2.829.

Firdaus, Aristhopan. "Aktualisasi Nilai-nilai Multikultural Melalui Penerapan Model Pembelajaran Kooperatif Tipe Jigsaw pada Mata Kuliah Studi Resolusi Konflik dan Pendidikan Multikultural." Jurnal PAI Raden Fatah, 1 (2): 209-226, https://doi.org/10.19109/pairf.v1i2.3250 .

Fransiska. "Menumbuhkan Nilai-nilai Multikultural di TK Graha Mulia Sintang." Dunia Anak: Jurnal Pendidikan Anak Usia Dini, 1 (1): 10-18, https://doi.org/10.31932/jpaud.v1i1.281.

Hanafi, Imam. "Neurosains-Spiritualitas dan Pengembangan Potensi Kreatif." An-Nuha: Jurnal Kajian Islam, Pendidikan, Budaya dan Sosial, 3 (1): 23-38.

Hasnida, Masyitoh, and Rusmin Tumanggor. "Spiritual Neuroscience Learning at Aisyiyah East of Tebet, South Jakarta." Asian Journal of Contemporary Education, 3 (2): 111-120, https://doi.org/10.18488/journal.137.2019.32.111.120.

Iqbal, Muhammad and Najmuddin. "Pendidikan Damai dalam Islam." Jurnal Ilmiah Sains, Teknologi, Ekonomi, Sosial dan Budaya, 1 (2): 66-72. 
Khoiriyah. "Pendidikan Anti-Radikalisme dan Strategi Menghadapinya: Ikhtiar Menyusutkan Gerakan Radikalisme di Indonesia." Tarbiyatuna: Jurnal Kajian Pendidikan Islam, 3 (2): 122 138, https://doi.org/10.29062/tarbiyatuna.v3i2.263.

Kosasih, Aceng Wawan Hermawan, and Supriyono. "Model Pendidikan Anti Teroris Melalui Internalisasi Nilai Dzikir di Pesantren." Jurnal Pendidikan Ilmu Sosial, 25 (1): 109, https://doi.org/10.17509/jpis.v25i1.3673.

Ma'arif, Syamsul. "Education as a Foundation of Humanity: Learning from the Pedagogy of Pesantren in Indonesia." JSSER: Journal of Social Studies Education Research, 9 (2): 104-123, https://doi.org/10.17499/jsser.58854.

Ma'arif, Syamsul Leonard C. Sebastian, and Sholihan Sholihan. "A Soft Approach to Counter Radicalism: The Role of Traditional Islamic Education." Walisongo: Jurnal Penelitian Sosial Keagamaan, 28 (1): 1-28, https://doi.org/10.21580/ws.28.1.6294.

Marhayani, Dina Anika et. al. "The Socialization of Patriotism Through the Screening of the National Defense Film Against Border Area Communities." International Journal of Public Devotion, 2 (2): 44, http://dx.doi.org/10.26737/ijpd.v2i2.1643.

Muchith, Muhammad Saekan. "Radikalisme dalam Dunia Pendidikan." Addin: Media Dialektika Ilmu Islam, 10 (1): 163-180, http://dx.doi.org/10.21043/addin.v10i1.1133.

Muhimmah, Imroatum and Suyadi. "Neurosains dan Spiritualitas dalam Pendidikan Islam." Tadris: Jurnal Pendidikan Islam, 15 (1): 68-87, https://doi.org/10.19105/tjpi.v15i1.2880.

Muzamil. "Mewujudkan Pendidikan Jihad untuk Melawan Teroris." Turatsuna: Jurnal Keislaman dan Pendidikan, 1 (1): 79-87.

Pardede, Sulastry. "Penerapan Terapi Suportif dengan Teknik Bimbingan untuk Mengurangi Dorongan Bunuh Diri pada Pasien Skizofrenia." Teraputik Jurnal Bimbingan dan Konseling, 1 (1): 89-96.

Pasiak, Taufiq Fredrik. Model Penjelasan Spiritualitas dalam Konteks Neurosains. Dissertation, UIN Sunan Kalijaga, Yogyakarta, 2009.

Rasyid, Muhammad Makmun. "Islam Rahmatan Lil Alamin Perspektif KH. Hasyim Muzadi." Epiteme: Jurnal Pengembangan Ilmu Keislaman, 11 (1): 93-116, https://doi.org/10.21274/epis.2016.11.1.93-116.

Rohman, Fathur. 'Pendidikan Islam Anti Radikalisme Melalui Nadham: Telaah Kitab Shifa' Al-Ummah Karya KH. Taufiqul Hakim Bangsri Jepara." Tadris: Jurnal Pendidikan Islam, 13 (1): 78-93, https://doi.org/10.19105/tjpi.v13i1.1757.

Rofiq, Ach. "Living Aswaja sebagai Model Penguatan Anti Radikalisme di Pesantren." Tarbawi Jurnal Pendidikan Islam, 16 (1): 1-13, https://doi.org/10.34001/tarbawi.v16i1.997.

Saihu and Marsiti. "Pendidikan Karakter dalam Upaya Menangkal Radikalisme di SMA Negeri 3 Kota Depok, Jawa Barat." Andragogi: Jurnal Pendidikan Islam dan Manajemen Pendidikan Islam, 1 (1): 23-54, https://doi.org/10.36671/andragogi.v1i1.47.

Sya'roni, Muh. "Strategi Integrasi Pendidikan Anti Radikalisme dalam Kurikulum SMA/MA." Karangan: Jurnal Kependidikan, Pembelajaran, dan Pengembangan, 1 (1): 37-45.

Deradicalization Based on Spiritual Neuroscience | Heni Listiana 
Ulifah, Desi and I Made Suwansa. "Strategi Sekolah dalam Menanamkan Sikap Cinta Tanah Air Pada Peserta Didik di SMPN 1 Tarik Kabupaten Sidoarjo." Kajian Moral dan Kewarganegaraan, 8 (3): 871-886.

Umro, Jakaria. "Upaya Guru Pendidikan Agama Islam dalam Mencegah Radikalisme Agama di Sekolah." JIE: Journal of Islamic Education, 2 (1): 89-108.

Usman, Abd. Malik. "Islam Rahmah dan Wasathiyah: Paradigma Keberislaman Inklusif, Toleran dan Damai." Humanika: Kajian Ilmiah Mata Kuliah Umum, 15 (1): 1-13, https://doi.org/10.21831/hum.v15i1.7637.

Wiyani, Novan Ardy "Pendidikan Agama Islam Berbasis Anti Terorisme di SMA." Jurnal Pendidikan Islam, 2 (1): 65-83, https://doi.org/10.14421/jpi.2013.21.65-83.

Wiyanto. "Implementasi Nilai-nilai Multikultural pada Sekolah Multietnik: Studi Interaksi Sosial di SMA Karangturi." Ecodunamika: Jurnal Pendidikan Ekonomi, 1 (3): 1-5. 